\title{
ANALISIS FUNGSI PENGHIMPUNAN, PENDISTRIBUSIAN, DAN PEMBERDAYAAN DALAM MELAYANI MUSTAHIK PADA MASA PANDEMI COVID-19 DI BAZNAS PROVINSI BALI
}

\author{
Bahrullah $^{1}$, Kurniawati ${ }^{2}$, Iswahyuni ${ }^{3}$ \\ ${ }^{1,2,3}$ Program Studi Ekonomi Syariah, Sekolah Tinggi Agama Islam Denpasar Bali, \\ Denpasar, Indonesia \\ e-mail: \{bahrullahalfaruq099@gmail.com, kurniawati.aam@gmail.com, \\ iswahyunijenar@gmail.com\}
}

\begin{abstract}
ABSTRAK
Terpuruknya perekonomian akibat pandemi covid-19 ini mengakibatkan masyarakat sulit dalam memenuhi kebutuhan sehari-hari. Oleh karena itu, Sebagai lembaga nonstruktural BAZNAS Provinsi Bali selalu dituntut untuk memberikan pelayanan yang optimal kepada mustahik khususnya. Penelitian ini fokus mengkaji tentang: (1) Bagaimanakah Penghimpunan BAZNAS Dalam Melayani Muzakki Pada Masa Pandemi Covid-19 Di BAZNAS Provinsi Bali. (2) Bagaimanakah Pendistribusian BAZNAS Dalam Melayani Mustahik Pada Masa Pandemi Covid19 Di BAZNAS Provinsi Bali. (3) Bagaimanakah Pemberdayaan BAZNAS Dalam Melayani Mustahik Pada Masa Pandemi Covid-19 Di BAZNAS Provinsi Bali. Adapun Tujuan Penelitian ini adalah (1) Untuk Mengetahui Penghimpunan BANAS Dalam Melayani Muzakki Pada Masa Pandemi Covid-19 Di BAZNAS Provinsi Bali. (2) Untuk Mengetahui Pendistribusian BAZNAS Dalam Melayani Mustahik Pada Masa Pandemi Covid-19 Di BAZNAS Provinsi Bali. (3) Untuk Mengetahui Pemberdayaan BAZNAS Dalam Melayani Mustahik Pada Masa Pandemi Covid-19 Di BAZNAS Provinsi Bali. Jenis penelitian ini adalah deskriptif kualitatif. Informan dipilih dengan menggunakan teknik Purposive sampling. Teknik untuk memperoleh data yang valid dan akurat, yaitu; wawancara, observasi, dan dokumentasi. Keabsahan data meliputi; kekuatan pengamatan dan triangulasi. Teknik analisis data meliputi; reduksi data, penyajian data dan pengambilan keputusan. Hasil penelitian menunjukkan bahwa (1) Penghimpunan BAZNAS Dalam Melayani Mustahik Pada Masa Pandemi covid-19 meliputi; (a) edukasi (dengan melibatkan donatur saat penyaluran), (b) promosi (melalui media cetak, media sosial, dan media eletronik), pertanggungjawaban (melalui audit oleh akuntan publik, dan audit syar'i), (2) Pendistribusian yang dilakukan oleh BAZNAS Provinsi Bali yaitu (a) distribusi konsumtif tradisional, (b) distribusi konsumtif kreatif, (c) distribusi produktif tradisional, dan (d) distribusi produktif kreatif. (3) Pemberdayaan yang dilakukan oleh BAZNAS Provinsi Bali yaitu (a) mengembangkan, (memandirikan mustahik), (b) menswadayakan, (melindungi, membela, dan berpiha kepada yang lemah melalui Pelayanan yang Universal).
\end{abstract}

\section{Kata kunci: Penghimpunan, Pendistribusian, Pemberdayaan, Pelayanan Mustahik.}

\footnotetext{
ABSTRACT

The downturn in the economy due to the Covid-19 pandemic has made it difficult for people to meet their daily needs. Therefore, as a non-structural institution, BAZNAS Bali Province is always required to provide optimal services to mustahik in particular. This research focuses on examining: (1) How to collect BAZNAS in serving Muzakki during the Covid-19 pandemic at BAZNAS, Bali Province. (2) How was the distribution of BAZNAS in serving Mustahik during the Covid-19 pandemic at BAZNAS, Bali Province. (3) How to Empower BAZNAS in Serving Mustahics during the Covid-19 Pandemic at BAZNAS, Bali Province. The objectives of this study are (1) to determine the collection of BANAS in serving Muzakki during the Covid-19 pandemic at BAZNAS, Bali Province. (2) To find out the distribution of BAZNAS in serving Mustahik during the Covid-19 pandemic at BAZNAS, Bali Province. (3) Knowing the Empowerment of BAZNAS in Serving Mustahics during the Covid-19 Pandemic at BAZNAS, Bali Province. This type of research is descriptive qualitative. Informants were selected using purposive sampling technique. Techniques to obtain valid and accurate data, namely; interviews, observation,
} 
and documentation. Data validity includes; power of observation and triangulation. Data analysis techniques include; data reduction, data presentation and decision making.

The results showed that (1) the collection of BAZNAS in serving Mustahik during the Covid-19 pandemic includes; (a) education (by involving donors during distribution), (b) promotion (through print media, social media, and electronic media), accountability (through audits by public accountants, and syar'i audits), (2) distribution carried out by BAZNAS Bali Province, namely (a) traditional consumptive distribution, (b) creative consumptive distribution, (c) traditional productive distribution, and (d) creative productive distribution. (3) Empowerment carried out by BAZNAS Bali Province, namely (a) developing, (empowering mustahik), (b) self-empowering, (protecting, defending, and looking after the weak through Universal Service).

Keywords: Collection, Distribution, Empowerment, Mustahik Services.

\section{PENDAHULUAN}

Pada akhir 2019 dunia dihadapkan pada satu wabah yang mematikan yang berasal dari kota Wuhan provinsi Hubei, Tiongkok, China yaitu virus COVID-19 atau Corona Virus Disease 19. Satu persatu korban meninggal akibat dari virus ini berjatuhan. Tidak hanya puluhan, ratusan, ataupun ribuan korban, bahkan jutaan korban disetiap negara. Sungguh suatu tragedi bencana yang luar biasa.

Tidak bisa dipungkiri bahwa Covid-19 telah mengguncang peradaban manusia didunia. Setiap negara melalui otoritasnya meminta rakyatnya untuk tetap dirumah masing-masing, menjaga jarak baik secara fisik (phyisical distncing) maupun sosial (sosial distancing) bahkan melakukan Lockdown (karantina wilayah) untuk menghambat penyebaran Covid-19 ini. Dampak covid-19 ini juga menyebabkan perekonomian dunia memburuk. Bahkan, Lembaga Keuangan dunia seperti International Monetary Fund (IMF) telah memperoyeksikan bahwa ekonomi global tumbuh minus diangka $3 \%$.

Pandemi Covid-19 ini memberikan banyak dampak terhadap kehidupan manusia khususnya perekonomian masyarakat. Salah satu dampak terhadap perekonomian rakyat indonesia adaalah banyaknya pekerja yang dirumahkan dan bahkan sampai pada PHK (Pemutusan Hubungan Kerja). Hal ini sungguh membuat ekonomi masyarakat menjadi terpuruk.

Terpuruknya perekonomian yang disebabkan covid-19 menyebabkan sulitnya memenuhi kebutuhan sehari-hari. Oleh karena itu, setiap lembaga pemerintah khususnya BAZNAS Provinsi Bali sebagai lembaga nonstruktural memiliki peran yang sangat penting guna melayani nantinya bisa membantu pemerintah masyarakat melalui fungsi penghimpunan, pendistribusian, dan pemberdayaan yang dalam rangka melayani sosial pada masa pandemi ini.

Allah SWT berfirman dalam surat AnNahl ayat 90, sebagai berikut:

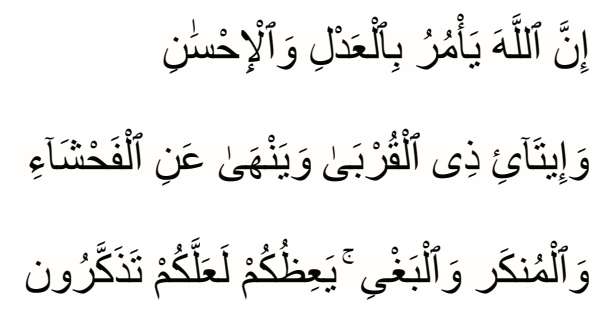

Artinya: "Sesungguhnya Allah menyuruh (kamu) berlaku adil dan berbuat kebajikan, memberi kepada kaum kerabat dan Allah melarang kamu dari berbuat keji, kemungkaran dan permusuhan. Dia memberi pengajaran kepadamu, agar kamu mengambil pelajaran". ${ }^{.}$

Ayat diatas memerintahkan kepada kita untuk berlaku adil serta berbuat baik terhadap sesama, membantu sesama dengan memberikan hak-hak mereka, lebih-lebih pada saat pandemi covid-19 ini, saling mencegah (melindungi) dari hal yang keji dan munkar, serta dituntut untuk menjaga persaudaraan antar sesama manusia.

Melayani masyarakat khususnya mustahik ditengah pandemi dengan menjaga tetap bergulirnya roda ekonomi dan terpenuhinya kebutuhan dasar mustahik menjadi salah satu tujuan BAZNAS. Untuk itu, Kebangkitan BAZNAS merupakan momentum untuk menjadikan zakat sebagai pilar

\footnotetext{
${ }^{1}$ Departemen Agama Republik Indonesia, $\mathrm{Al}$ Qur'an Terjemah, (Gedung GIP Kalibata: Al-Huda, 2002), h. 278
} 
pemoderasian kesenjangan sosial, kebangkitan ekonomi kerakyatan, terobosan dalam pengentasan kemiskinan, dan pengembangan sumber pendanaan pembangunan kesejahteraan umat di luar APBN. Untuk mencapai Kebangkitan Zakat ini dibutuhkan adanya kesadaran kolektif dari pelaku perzakatan nasional, peningkatan kapasitas kelembagaan dan amil, serta implementasi regulasi zakat nasional.

\section{METODE PENELITIAN}

Penelitian ini menggunakan metode deskriptif dengan pendekatan kualitatif. Alasan penulis menggunakan pendekatan kualitatif karena peneliti ingin menggambarkan secara jelas tentang obyek penelitian. Selain itu dengan menggunakan metode kualitatif, data yang didapat akan lebih lengkap, lebih mendalam, kredibel, dan bermakna. Jenis penelitian kualitatif yang dipilih untuk penelitian ini adalah penelitian deskriptif. Metode deskriptif tersebut digunakan untuk mendeskripsikan suatu peristiwa yang telah terjadi untuk mendapatkan suatu fakta yang berkaitan dengan menguraikan secara mendalam mengenai analisis fungsi penghimpunan, pendistribusian, dan pemberdayaan dalam melayani mustahik pada masa pandemi covid-19 di BAZNAS Provinsi Bali.

Penentuan informan dalam penelitian ini bersifat purposive. Pemilihan informan dilakukan karena mungkin saja peneliti telah memahami bahwa informasi yang dibutuhkan dapat diperoleh dari satu kelompok sasaran tertentu yang mampu memberikan informasi yang dikehendaki karena mereka memang memiliki informasi seperti itu dan mereka memenuhi kriteria yang ditentukan oleh peneliti. $^{2}$

Untuk mendapatkan data atau informasi, digunakan; pertama, teknik observasi, penulis mengadakan penelitian secara teliti terlebih dahulu situasi yang ada di BAZNAS Provinsi Bali serta mencatat situasi kerja dan kegiatan lainnya secara sistematis; kedua, teknik wawancara dengan Ketua dan Staff Harian BAZNAS Provinsi Bali, serta 5 dari mustahik BAZNAS Provinsi Bali; dan ketiga, teknik

\footnotetext{
${ }^{2}$ Augusty Ferdinand, Metode Penelitian Manajemen, (Semarang: Badan Penerbit Universitas Diponegoro, 2006), h.56
}

dokumentasi, informasi atau data yang penulis dapatkan dari dokumen-dokumen yang terdapat di BAZNAS Provinsi Bali.

Teknik dalam menguji keabsahan data yang di peroleh, peneliti menggunakan teknik kekuatan pengamatan dan triangulasi. kekuatan pengamatan merupakan salah satu teknik memperoleh data, informasi dilapangan kemudian dicocokkan dengan jawaban informan. Adapun triangulasi data yang penulis gunakan dalam penelitian ini adalah:

1. Triangulasi Sumber

Triangulasi sumber digunakan untuk menguji kredibilitas data yang dilakukan dengan cara mengecek data yang diperoleh melalui beberapa sumber. ${ }^{3}$ Jadi triangulasi sumber melakukan pengujian dengan melihat seluruh data yang diperoleh dari berbagai sumber untuk dicari hasil yang konkrit.

2. Triangulasi Teknik

Triangulasi teknik digunakan untuk mengkaji kredibilitas data yang dilakukan dengan cara mengecek data kepada sumber yang sama dengan teknik yang berbeda. ${ }^{4}$ Dengan melakukan pengecekan data kembali pada sumber yang sama, diharapkan mendapat data yang lebih akurat yang mana menggunakan teknik pengambilan data yang berbeda, misalnya menggunakan teknik observasi dan wawancara.

Langkah-langkah analisis data dalam penelitian diskriptif kualitatif ini, yaitu dengan; reduksi data, penyajian data, dan pengambilan keputusan. Reduksi data berupa proses pemilihan, pemusatan perhatian pada penyederhanaan, dan trasformasi data kasar yang muncul dari catatan tertulis di lapangan, yang dilakukan secara terus-menerus selama penelitian berlangsung. Penyajian data berupa penyajian data atau display data, yakni penyajian beberapa informasi yang tersusun dan memberi kemungkinan adanya penarikan simpulan dan pengambilan tindakan. Penarikan simpulan dimaksudkan untuk mencari makna data yang dikumpulkan dengan mencari hubungan, persamaan atau

${ }^{3}$ Lexy J. Moloeng, Metodologi Penelitian Kuantitatif, (Bandung: Remaja Rosdakarya, 1996), h.331

${ }^{4}$ Ibid. 
perbedaan dengan cara membandingkan kesesuaian pernyataan dari subyek penelitian dengan makna yang terkandung dalam konsep-konsep dasar penelitian. Sementara verifikasi data dimaksudkan agar penelitian tentang data-data bukti penelitian yang diteliti sesuai dengan maksud yang terkandung dalam konsep dasar penelitian ini.

\section{HASIL DAN PEMBAHASAN}

Hasil yang didapatkan berdasarkan data yang diperoleh melalui teknik pengumpulan data berupa observasi, wawancara, dan dokumentasi di BAZNAS Provinsi Bali, serta studi kepustakaan mengenai analisis fungsi penghimpunan, pendistribusian, dan pemberdayaan dalam melayani mustahik pada masa pandemi covid-19 di BAZNAS Provinsi Bali yang dilakukan oleh penulis, maka dapat di paparkan hasil penelitian dan pembahasan sebagai berikut.

\section{Penghimpunan yang dilakukan oleh BAZNAS Provinsi Bali}

Penghimpunan adalah kegiatan menghimpun dana dan mempengaruhi calon donatur, baik perseorangan maupun badan usaha, agar menyalurkan dana zakat, infak, dan sedekahnya kepada Lembaga Pengelola Zakat. ${ }^{5}$ Fundraising (penghimpunan) juga dapat diartikan sebagai kegiatan dalam rangka menghimpun dana dan sumber daya lainnya dari masyarakat (baik individu, kelompok, organisasi, perusahaan ataupun pemerintah) yang akan digunakan untuk membiayai program dan kegiatan operasional lembaga sehingga mencapai tujuan. ${ }^{6}$

Dijelaskan pula bahwa Fundraising (penghimpunan) adalah peroses mempengaruhi masyarakat baik perseorangan atau individu, baik perwakilan masyarakat atau lembaga agar menyalurkan dananya kepada sebuah organisasi. ${ }^{7}$

Berikut adalah metode penghimpunan yang dilakukan oleh BAZNAS Provisi Bali:

Pertama, melibatkan partisipasi donatur secara langsung (Direct Fundraising). Adapun

\footnotetext{
${ }^{5}$ Ahmad Furqon, Manajemen Zakat, (Semarang: CV Karya Abadi Jaya, 2015), h. 36

${ }^{6}$ Ahmad Juwaini, Panduan Direct Mail Untuk Fundrising, ( Depok: Piramedia, 2005), h. 4

${ }^{7}$ April Purwanto, Manajemen Fundraising Bagi Organisasi Pengelola Zakat, (Jakarta: TERAS, 2009), h. 12
}

yang dimaksud dengan direct fundraising ini yaitu mengajak donatur ketempat objek pelayanan BAZNAS Provinsi Bali, ataupun donatur tersebut berpesan tentqng alokasi dana yang telah disalurkan. Hal ini dijelaskan oleh Ketua BAZNAS Provinsi Bali sebagai berikut: "Eee yang dimaksud dengan melibatkan partisipasi donatur secara langsung itu ya, yang pertama eee pada waktu penyaluran ituu ee dia diajak ke objek ee apa itu yang mendapatkan apa itu pelayanan dari BAZNAS, dari penerima manfaat, Jadi di ajak. Yang kedua adalah bahwa apa itu eee donatur itu selain di ajak dia eee berpesan. Jadi kita menawarkan ini disalurkan dimana, kan ada ooo ini disalurkan dirumah yatim, begitu juga supaya disalurkan ke orang-orang miskin dan seterusnya. Nah itu jadi dia eee secara langsung ee terlibat ketika penyaluran dan secara langsung juga dia memesan ingin menyalurkan apa itu zakatnya kemustahik yang dia inginkan."

Selain dari melibatkan partisipasi donatur secara langsung dalam upaya menghimpun dana dari para donatur, BAZNAS Provinsi Bali juga melakukan berbagai promosi yang ditawarkan kepada masyarakat, baik promosi melalui Whatsapp, broadcast, sosial media, dan social charity (program peduli sosial) sehingga masyarakat tergugah hatinya untuk berdonasi melalui BAZNAS Provinsi Bali.

"Yaa promosinya banyaklaah, pake Whatsapp, broadcast, ada sosial media, ada program-program yang biasanya kita social charity (program peduli sosial). Misalnya ada yang sakit, ngga punya biaya, itu buat galang dana, itulah kita banyak apa namanya eee dampak positif sehingga donatur itu tertarik untuk membantu orang yang kita promosikan tadi."

Apalagi dengan kondisi yang menimpa saat ini, dengan adanya covid-19

\footnotetext{
${ }^{8}$ Mahrusun, Ketua BAZNAS Provinsi Bali, Wawancara Pribadi, Denpasar 11 Agustus 2020

${ }^{9}$ Ahmad Arrasyid, S.E. Selaku Staff Harian BAZNAS Provinsi Bali, Wawancara Terbuka, Denpasar 19 Agustus 2020
} 
meminimalisir kontak sosial secara langsung, dilarang berkerumunan, dan sebagainya. Dengan kata lain bahwa ruang gerak BAZNAS Provinsi Bali dalam melakukan penghimpunan dana secara langsung terbatasi, oleh karenanya Whatssapp, broadcast, dan sosial media menjadi salah satu wadah dalam aksi promosi untuk memikat hati donatur untuk berdonasi ke BAZNAS provinsi Bali, walaupun promosi lewat Whatssapp, broadcast, dan sosial media tidak lebih perfect (sempurna) jika dibandingkan dengan promosi secara langsung melalui sosialisasi face to face tadi, tapi apalah daya itulah yang terjadi saat ini.

Kedua, metode Fundraising tidak langsung (Indirect Fundraising). Jika dalam Fundraising langsung donatur terlibat dalam proses pendistribusian ZIS (Zakat, Infak, dan Sedekah), maka metode fundraising tidak langsung (Indirect Fundraising) adalah kebalikannya yang mengarah pada pembentukan citra lembaga.

Di BAZNAS Provinsi Bali sendiri, Ada berbagai cara untuk membangun citra lembaga, baik melalui proses Audit (Audit Akuntan Publik, dan Audit Syar'i), maupun memperbanyak distribusi program sosial dan publikasi melalui media sosial.

"Yaa selama ini ee apa itu untuk me ee membuat ee citra lembaga dengan berbagai cara ya seperti tadi misalkan dengan melakukan audit oleh akuntan publik. Kemudian juga eee sekarang sudah ada lagi yaitu audit syar'i, pegawai BAZNAS ini sudah di audit ee secara syar'i oleh lembaga kementrian agama. Maksudnya apa supaya penyaluran-penyaluran itu bertentangan dengan syar'i apa ndak. Aaa ukurannya kira-kira begitu sehingga yang dilakukan sesuai dengan syar'i." 10

"Banyakin penyaluran program sosial membantu orang dan publikasi ke sosial media dan WA broadcast, sehingga orang tau apa yang dikerjakan oleh BAZNAS Provinsi Bali". ${ }^{11}$

\footnotetext{
${ }^{10}$ Mahrusun, Ketua BAZNAS Provinsi Bali, Loc. Cit.

${ }^{11}$ Ahmad Arrasyid, Selaku Staff Harian BAZNAS Provinsi Bali, Loc. Cit.
}

Sistem penghimpunan yang dilakukan di BAZNAS Provinsi Bali menggunakan official assessment. "official assessment merupakan donasi akan dihitung dan dialokasikan oleh pihak yang berwenang, seperti badan-badan yang ditunjuk oleh pemerintah. Sistem ini didasari pada perintah Allah Swt., kepada para penguasa yang berwenang untuk mengambil ( $k h u d z$ ) sebagian dari kekayaan orang Islam yang berkecukupan". ${ }^{12}$

Di BAZNAS Provinsi Bali diterapkan sistem Official Assessment untuk penghimpunan zakat (beda lagi jika bicara infak, dan sedekah), sekarang bagaimana cara memberitahu muzakki/donatur bahwa zakat/donasinya telah dialokasikan oleh BAZNAS Provinsi Bali ? dijelaskan bahwa BAZNAS Provinsi Bali memiliki sistem informasi manajemen BAZNAS (SIMBA), didalamnya terdapat BSZ (Bukti setor Zakat), SMS konfirmasi dan sebagainya guna memberitahu muzakki/donatur bahwa zakat/donasinya telah diterima pihak BAZNAS dan siap untuk dialokasikan.

Selain itu BAZNAS Provinsi Bali juga setiap tahun menerbitkan brosur guna memberitahu donatur/muzakki tentang alokasi zakat/donasi yang telah disalurkan melalui BAZNAS Provinsi Bali.

\section{Pendistribusian BAZNAS dalam melayani mustahik pada masa pandemi covid-19.}

Distribusi berasal dari bahasa Inggris yaitu distribusi yang berarti pembagian atau penyaluran, secara terminologi distribusi adalah penyaluran (pembagian) kepada orang banyak atau beberapa tempat. Pengertian lain mendefinisikan distribusi sebagai penyaluran barang keperluan sehari-hari oleh pemerintah kepada pegawai negeri, penduduk, dan sebagainya. ${ }^{13}$

Menurut Philip Kotler "distribusi adalah serangkaian organisasi yang saling tergantung yang terlibat dalam proses untuk menjadikan produk atau jasa yang siap untuk digunakan atau dikonsumsi. Dalam hal ini distribusi dapat diartikan sebagai kegiatan

\footnotetext{
${ }^{12}$ Mursyidi, Akuntansi Zakat Kontemporer, ( Bandung: PT. Remaja Rosdakarya Offset, 2003), hal. 100-102.

${ }^{13}$ Tim Penyusun Kamus Pusat Bahasa, Kamus Besar Bahasa Indonesia, (Jakarta: Balai Pustka, 2005), h. 269
} 
(membagikan, mengirimkan) kepada orang atau kebeberapa tempat."14

Berikut merupakan distribusi yang dilakukan oleh BAZNAS Provinsi Bali dalam melayani mustahik pada masa pandemi covid19.

Pertama, Distribusi konsumtif tradisional. Distribusi konsumtif tradisional merupakan distribusi yang dibagikan kepada mustahik untuk dimanfaatkan secara langsung. ${ }^{15}$ pendistribusian zakat, infak, dan sedekah (ZIS) di BAZNAS Provinsi Bali pada saat pandemi ini diberikan kepada seluruh pihak yang terdampak covid-19.

Dengan kata lain bahwa distribusi yang dilakukan oleh BAZNAS Provinsi Bali tidak hanya semata untuk mustahik melainkan kepada siapapun yang terdampak covid-19. Proses yang dilakukan dengan cara melibatkan majelis taklim, dan seluruh komunitas. dengan tujuan seluruh komunitas tadi bisa merekomendasikan siapa saja pihak yang benar-benar membutuhkan bantuan akibat pandemi ini.

"Jadi disini terutama dimasa pandemi ini, bahkan kita selama ini ee hampir seluruhnya itu kita berikan kepada masyarakat. Bukan hanya pelayanan kepada mustahik. Ada yang kita layani itu ee apa itu di denpasar, ada yang diseluruh bali. Jadi kita distribusikan ke BAZNAS kabupaten kota. Eee dan kemudian oleh BAZNAS ini diberikan kepada mustahik. Karena kita kan eee tidak tahu seluruhnya mengenai mustahik seluruh bali. Jadi kita serahkan ke BAZNAS kabupaten/kota." ${ }^{\prime 16}$

"Hmm naah prosesnya itu kita melibatkan majelis taklim, terus seluruh komunitas biar tidak tumpang tindih. Kita cari yang benar-benar membutuhkan. Kayak kemarin itu kita

\footnotetext{
${ }^{14}$ Fandy Tjiptono, Strategi Pemasaran, Loc.
} Cit.

${ }^{15}$ Riyantama Wiradifa dan Desmadi saharuddin, "Strategi Pendistribusian Zakat, Infak, Dan Sedekah (ZIS) Di Badan Amil Zakat Nasional (BAZNAS) Kota Tanggerang selatan”, Loc. Cit.

${ }^{16}$ Mahrusun, Ketua BAZNAS Provinsi Bali, Loc. Cit. make temen-temen driver, gojek, go car dan sebagainya. Kita minta tolong, temen-temen bapak yang benar-benar tidak punya pendapatan sama sekali karena terjadinya Covid-19 ini. Kalau kemarin ini kita banyak sembako. Kalau biasanya kita asumsikan kualitas bukan kuantitas. Kalau di Covid ini kualitasnya sedikit dan kuantitasnya banyak, biar merata." 17

Apa yang dilakukan oleh BAZNAS Provinsi Bali terkait dengan melibatkan majelis taklim dan seluruh komunitas dengan tujuan mendapatkan rekomendasi diatas, dapat kita anggap sebagai aksi yang valid, secara pihak BAZNAS Provinsi Bali tidak akan turun sendiri mencari mustahik yang ada dengan keterbatasan akibat pandemi ini.

Penyaluran saat pandemi ini tentunya sangat berbeda dengan penyaluran tahun-tahun sebelumnya. Seperti halnya penyaluran sembako pada saat pandemi ini harus mematuhi protokol kesehatan penanganan Covid-19 seperti halnya jaga jarak dan memakai masker. Pembagiaan sembako yang dilakukan oleh BAZNAS Provinsi Bali berisikan bahan pokok makanan ( Beras 5 kilo, Mie Instan, Telur, minyak Goreng) dengan nominal yang berbeda sesuai dengan penyaluran.

Kedua, Distribusi kosumtif kreatif. Distribusi konsumtif merupakan distribusi yang diwujudkan dalam bentuk lain dari barangnya semula, contohnya seperti alat-alat sekolah dan beasiswa. ${ }^{18}$ Distribusi yang dilakukan oleh BAZNAS Provinsi Bali yang diwujudkan dalam bentuk beasiswa tadi tentunya tidak sembarangan memberikan kepada mustahik. pertanyaannya, kriteria mustahik seperti apa yang mendapatkan distribusi dalam bentuk beasiswa ? ternyata BAZNAS Provinsi Bali memilih kriteria sebagai berikut: IPK minimal 3, ada peryataan aktif kuliah, aktif organisasi, dan berprestasi. Dengan kata lain Terbatas dalam materi namun bagus dalam akademik.

\footnotetext{
${ }^{17}$ Ahmad Arrasyid, Selaku Staff Harian BAZNAS Provinsi Bali, Loc. Cit.

${ }^{18}$ Riyantama Wiradifa dan Desmadi saharuddin, "Strategi Pendistribusian Zakat, Infak, Dan Sedekah (ZIS) Di Badan Amil Zakat Nasional (BAZNAS) Kota Tanggerang selatan", Loc. Cit.
} 
Kriteria diatas tentunya melewati survei dan penelitian terlebih dahulu oleh pihak BAZNAS Provinsi Bali. Namun bagaimana jika ada mustahik yang memperoleh beasiswa tersebut tidak menggunakan beasiswanya dengan baik ? entah itu IPK nya menurun ataupun sebagainya. Maka BAZNAS Provinsi Bali akan di Blacklist dan beasiswanya.

"Langsung kita BlackList, langsung kita panggil dan suruh kembalikan lagi. kayak kemarin salah satunya ada yang memanipulasi data eee KHS, sekarangkan serba teknologi ya, jadi KHS nya itu mungkin nilainya jelek atau apa, tapi dikasi dengan nilai yang sama tapi diganti dengan tahun, ketahuan kita putus langsung beasiswanya dan beasiswanya yang terakhir tidak kita bayarkan."19

Selain dari kriteria mustahik dan aksi yang dilakukan BAZNAS Provinsi Bali terhadap mustahik yang tidak mengguanakan beasiswa dengan baik, ada letak perbedaan BAZNAS provinsi Bali dengan pemberi beasiswa lainnya. Bahwa BAZNAS Provinsi Bali tidak mengharapkan timbal balik dari mustahik tersebut, dengan kata lain mustahik yang mendapatkan beasiswa dari BAZNAS Provinsi Bali mendapatkan kebebasan (ada timbal balik ataupun tidak), namun hanya sekedar menghimbau untuk mengabdikan diri di BAZ/LAZ setempat atau setidaknya mencari satu donatur saja untuk BAZNAS Provinsi Bali.

"Yaa jadi begini pada dasarnya uang ataupun biaya yang dikeluarkan BAZNAS itu kan eee tidak harus ada imbalannya. Kita memberikan sesuai dengan kewajiban kita selaku pengurus pada masyarakat. Tidak ada ikatan. Jadi kalau tadi saya sampaikan itu adalah sifatnya anjuran. Yaa kalau misalnya mereka nggak anu yaa nggak apa-apa. Memang seringkali BAZNAS ZIS itu digambarkan bahwa ini harus eee apa itu eee

${ }^{19}$ Ahmad Arrasyid, Selaku Staff Harian BAZNAS Provinsi Bali, Loc. Cit nanti bisa kembali, nggak. Ada yang mengatakan harus kembali. Sama misalkan kalau di Bank itu qordul hasan ya sudah diberikan begitu saja." 20

\section{Pemberdayaan yang dilakukan oleh BAZNAS Provinsi Bali}

Pemberdayaan merupakan penyaluran dana yang disertai target yang tidak dapat dengan mudah atau dalam waktu yang singkat dapat terealisasi. Karena itu, penyaluran dana tersebut harus disertai dengan pemahaman yang utuh terhadap permasalahan yang ada pada masyarakat sebagai penerima dana. Apabila permasalahannya adalah kemiskinan, harus diketahui penyebab kemiskinan tersebut, sehingga dapat mencari solusi yang tepat demi tercapainya target yang telah direncanakan. ${ }^{21}$

Kemandirian mustahik menjadi salah satu target dalam pengembangan ini. Hal ini tentu memiliki proses yang sangat panjang, dan perjuangan yang sangat keras. Baik dari pihak BAZNAS Provinsi Bali dalam hal mengontrol, maupun dari mustahik itu sendiri berupa kemauan dan semangat untuk berubah menjadi lebih baik.

BAZNAS Provinsi Bali dalam mendistribusikan ZIS (Zakat, Infak, dan Sedekah) bukan semata-mata memenuhi kewajiban saja sebagai amil, akan tetapi lebih dari sekedar itu yaitu memandirikan mustahik, bagaimana agar mustahik yang menerima distribusi dari BAZNAS Provinsi Bali menjadi muzakki. Tolak ukur mustahik yang mandiri sebagaimana yang dijelaskan oleh Ketua BAZNAS Provinsi bali sebagai berikut:

"Yaa terukurnya dia setelah dia berikan bantuan usahanya lancar. Misalnya begitu ya eee bagi yang selama ini barangkali, ee keluhan paling banyak kan diantaranya kekurangan modal. Kalau setelah satu tahun dua tahun dia sudah bisa berjalan berarti sudah bisa mandiri gitu. Yaa memang ini memerlukan pemantauan dari kita secara terus menerus, sehingga apa ini bisa anu

\footnotetext{
${ }^{20}$ Mahrusun, Ketua BAZNAS Provinsi Bali, Loc. Cit.

${ }^{21}$ Muhammad Hasan, Manajemen Zakat Model Pengelolaan yang Efektif, Loc. Cit.
} 
bisa jalan. Kalau misalkan satu-dua tahun masih gagal ya kita coba lagi, kalau ndak ya kan banyak yang memerlukan. Kita konsentrasinya bukan dia saja, ada yang lain juga." 22

Bentuk pengembangan dan swadaya yang diberikan oleh BAZNAS Provinsi Bali saat pandemi ini berbentuk program beasiswa SKSS (Satu Keluarga Satu Sarjana) yang diberikan kepada mustahik yang memenuhi kriteria tertentu sebagaimana yang telah penulis singgung sebelumnya dalam distribusi produktif.

Semua fungsi penghimpunan, pendistribusian, dan pemberdayaan yang dilakukan oleh BAZNAS Provinsi Bali Semua Proses diatas tentunya ditunjang atau didukung oleh Tangibles atau bukti fisik yang berupa fasilitas yang dimiliki oleh BAZNAS Provinsi Bali. walaupun Fasilitas yang berupa gedung BAZNAS Provinsi Bali masih belum milik sendiri (sewa), oleh karena BAZNAS Provinsi Bali tidak mendapatkan dana operasioanl dari pemerintah untuk pembuatan kantor sendiri.

Menyewa "Menyewa, karena apa, karena memang kita tidak diberikan dana untuk eee apa itu mempunyai kantor sendiri, sehingga apa seluruh BAZNAS di Bali ini ada yang menginduk ke KUA ada, kemudian ada juga, ini ada dua di Bali ini yang mempunyai kantor sendiri di Buleleng dan di Jembrana. Sehingga pelayanan sepenuhnya dilakukan sendiri oleh mereka dikantor mereka sendiri. Kalau disini ya masih belum." 23

Selain dari gedung, hal yang tidak kalah penting untuk diperhatikan untuk memaksimalkan pelayanan adalah akses menuju kantor BAZNAS Provinsi Bali. Sebagaimana yang disampaikan oleh ketua BAZNAS Provinsi Bali sebagai berikut:

\footnotetext{
${ }^{22}$ Mahrusun, Ketua BAZNAS Provinsi Bali, Loc. Cit.

${ }^{23}$ Mahrusun, Ketua BAZNAS Provinsi Bali, Loc. Cit.
}

"Yaa saya kira karena jalur utama ya eee tidak masalah. kecuali kalau misalkan masuk gang jauh. Dan selama ini orang-orang yang langsung membayarkan zakatnya kesini dan mereka tidak mengeluh. Ya terutama kan ada yang bayar zakatnya kesini ada, kemudian yang lewat perbankan ada, ada yang supaya diambil oleh kita ada,jadi mengenai keberadaan kantor ini dulu juga sudah kita perhitungkan, jangan sampai menyulitkan untuk pemberian pelayanan. Lewat jalan sana ya bisa kan gitu, kemudian yang sini juga bisa." 24

Perlengkapan menjadi salah satu bagiaan dalam menopang kinerja pegawai BAZNAS Provinsi Bali dalam melayani mustahik. Dalam memberikan pelayanan kepada mustahik BAZNAS Provinsi menggunakan kendaraan berupa mobil Ambulance dan motor.

Selain dari fasilitas, perlengkapan, dan peralatan, yang tak kalah penting yang harus diperhatikan dalam memberikan sebuah pelayanan adalah penampilan pegawai. Assurance atau jaminan dan kepastian. Assurance atau jaminan dan kepastian merupakan pengetahuan, kesopansantunan, dan kemampuan para pegawai perusahaan untuk menumbuhkan rasa percaya para pelanggan kepada perusahaan. ${ }^{25}$

Pengetahuan pegawai dalam menumbuhkan rasa percaya masyarakat juga penting, kenapa? Karena biasanya masyarakat atau mustahik khususnya akan merasa senang jika pegawai BAZNAS Provinsi Bali mengetahui apa saja yang menjadi indikator kepercayaannya.

Di BAZNAS Provinsi Bali yang harus diketahui oleh pegawainya terutama staff oprasional adalah harus pintar publikasi dengan cara yang baik, bahasa yang baik, dan tidak kalah penting ada pelaporan baik itu penerimaan dan penayaluran donasi/zakat.

Selain dari pengetahuan yang harus dimiliki oleh pegawai BAZNAS Provinsi Bali, sopan santun juga menjadi sesuatu yang tidak

\footnotetext{
${ }^{24}$ Ibid

${ }^{25}$ Parasuraman dan Berry, SERVQUAL: A

Multiple Item Scale For Measuring Consumer

Perceptions Of Service Quality, Loc. Cit.
} 
bisa dikesampingkan. Sebab seberapapun pengetahuan yang dimiliki jika tidak dibarengi dengan sopan santun yang baik, akan memberi kesan yang buruk terhadap mustahik yang mendapatkan sebuah pelayanan dari BAZNAS Provinsi Bali.

Sebagai lembaga yang melayani kebutuhan mustahik khususnya tentunya ada beberapa kebutuhan konsumen yang belum terpenuhi oleh karena keterbatasan dana. Hal ini diakui oleh informan A.2 pada koding 2.34. hal ini penulis kira adalah sesuatu yang wajar jika kita melihat bahwa BAZNAS Provinsi Bali tidak mendapatkan support (dukungan) dana dari pemerintah meskipun BAZNAS Provinsi Bali sebagai lembaga nonstruktural adanya.

\section{PENUTUP}

Berdasarkan hasil penelitian, analisis data, dan pembahasan mengenai "Analisis Fungsi Penghimpunan, Pendistribusian, dan Pemberdayaan Dalam Melayani Mustahik Pada Masa pandemi Covid-19 di BAZNAS Provinsi Bali." Maka dapat diambil kesimpilan sebagai berikut:

Pertama, Dari penelitian ini, maka peneliti dapat menyimpulkan bahwa penghimpunan yang dilakukan oleh BAZNAS provinsi Bali yaitu (a) edukasi (dengan melibatkan donatur saat penyaluran), (b) promosi (melalui media cetak, media sosial, dan media eletronik), (c) pertanggungjawaban (melalui audit oleh akuntan publik, dan audit syar'i), serta (d) menjalin hubungan yang baik dengan muzakki/donatur melalui WA Broadcast, ada BSZ (Bukti Setor Zakat), ada konfirmasi SMS, dan brosur.

Kedua, Pendistribusian yang dilakukan oleh BAZNAS Provinsi Bali yaitu (a) distribusi bersifat konsumtif tradisional, (b) distribusi bersifat konsumtif kreatif, (c) distribusi bersifat produktif tradisional, dan (d) distribusi dalam bentuk produktif kreatif.

Ketiga.pemberdayaan yang dilakukan oleh BAZNAS Provinsi Bali meliputi mengembangkan mustahik yang meliputi memandirikan, dan menswadayakan yang meliputi melindungi, membela, dan berpihak kepada yang lemah.

\section{DAFTAR RUJUKAN}

Al-Quran

Al-Qur'an Terjemah, Departemen Agama

Republik Indonesia (Gedung GIP

Kalibata: Al-Huda, 2002)

\section{Buku}

Furqon, Ahmad. 2015. Manajemen Zakat. Semarang: CV. Karya Abadi Jaya

Fuzna Ulya, Luthfiana. 'Iplementasi Pasal 30 Undang-Undang Republik Indonesia Nomor 23 tahun 2011 tentang Pembiayaan Badan amil Zakat Nasional Di BAZNAS Kota Semarang", Skripsi, (Semarang: UIN Walisongo, 2016), (td)

Hasan, Muhammad. 2011. Manajemen Zakat Model Pengelolaan yang Efektif. Yogyakarta: Idea Press

Ismatulloh, Irpa. "Sistem pelayanan Badan Amil Zakat Nasional (BAZNAS) Kota Bogor Dalam Perspektif Good Corporate Governance”, Skripsi, (Jakarta: Perpus IAIN Syarif Hidayatullah, 2015), (td)

Juwaini, Ahmad. 2005. Panduan Direct Mail Untuk Fundrising, Depok: Piramedia

Kottler, Philip. 1994. Marketing Manajemen: Analisis Planning, Iplementation and Control, Eight Edition, New Jersey. Alih Bahasa Herujati Purwoko: Prentice Hal Mas'udi, Masdar Farid. 2005. Pajak Itu Zakat: Uang Allah untuk Kemaslahatan Rakyat. Bandung: Mizan Pustaka

Munir. 2006. Manajemen Pelayanan Umum. Jakarta: Bumi Aksara

Mursyidi,. 2003. Akuntansi Zakat

Kontemporer. Bandung: PT.

Remaja Rosdakarya Offset

Purwanto, April. 2009. Manajemen

Fundraising Bagi Organisasi

Pengelola Zakat. Jakarta: TERAS

Parasuraman dan Berry. 2012.

SERVQUAL: A Multiple Item Scale

For Measuring Consumer

Perceptions Of Service Quality. Juornal Of Retailing

Sugiyono. 2017. Statistik Untuk Penelitian. Bandung: Alfabeta 
2011. Metode Penelitian Kuantitatif dan Kualitatif $R \& D$. Bandung:

Alfabeta

$\begin{array}{ccc}2017 . & \text { Metode } & \text { Penelitian } \\ \text { Kombinasi } & \text { (Mixed } & \text { Methods), }\end{array}$

(Bandung: Alfabeta

Tjiptono, Fandy. 2001. Strategi

Pemasaran. Yogyakarta: Andi

Wiratna Suajrwerni, V. 2015. Metodologi Penelitian Bisnis dan Ekonomi. yogyakarta: pustakabarupress

Wiradifa, Riyantama, et al. 2020. Jurnal Ekonomi dan Bisnis Islam IAIN. Samarinda

\section{Pernyataan lisan}

Arrasyid, Ahmad. Selaku staff harian BAZNAS Provinsi Bali. Wawncara pribadi. Denpasar 19 Agustus 2020

Agustina, Diana. Mustahik BAZNAS

Provinsi Bali. Wawancara pribadi. Denpasar 25 Agustus 2020

Ahmad. Mustahik BAZNAS Provinsi Bali.

Wawancara Google Form.

Denpasar 26 agustus 2020

Agustin, Dewi. Mustahik BAZNAS

Provinsi Bali. Wawancara Google

Form. Denpasar 26 Agustus 2020

Mahrusun. Ketua BAZNAS provinsi Bali.

Wawancara pribadi. Denpasar 11 agustus 2020

N, Fathurrahman. Musthaik BAZNAS Provinsi Bali. Wawancara Google Form. Denpasar 26 Agustus 2020

Suartini, Luh. Mustahik BAZNAS Provinsi Bali. Wawancara Google Form 26

Agustus 2020 